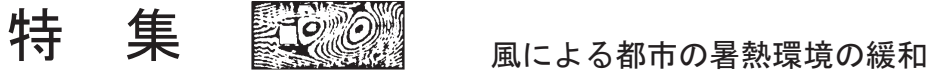

\section{気象・都市スケールの温熱環境 \\ Thermal Environment of City-Scale in the Meteorology}

日下博幸* 1

Hiroyuki KUSAKA

\section{1.まえがき}

「気象・都市スケールの温熱環境」というタイトルで 本誌解説を依頼されたとき, 気象学分野における都市ス ケールの温熱環境の話を書くことが望まれている，と理 解しました。そこで, 本稿では, 気象学分野における都 市スケールの温熱環境について, 歴史的な流れも意識し ながら, 最近の取り組みについて紹介したいと思います。 ただ，私が数值シミュレーションの研究を多く行ってい ることや, 最近の都市スケールの温熱環境の研究の多く が数值シミュレーションに関するものであることから， 数值シミュレーションの話題が中心になることをご了承 ください。また，都市スケールでの温熱環境とエネルギ 一需要の関係や, 温熱環境と都市計画の関係, 温熱環境 と健康の関係なども重要なテーマですが，これらはそれ ぞれの専門家の方に解説してもらったほうが良いと判断 したので，本稿では割愛することにしました。

気象学・気候学の一分野である都市気象学・都市気候 学分野では, 伝統的には, メソスケール（都市～都市圈 スケール）の温熱環境を主として扱ってきました。なぜ ならば, 1833 年にルーク・ハワードによって（ロンドン の気候という著書で）ヒートアイランド現象が紹介され てから, 都市気象学・都市気候学の主な研究対象は, ヒ ートアイランド現象であり，その目的は「なぜ都市は郊 外よりも気温が高くなるのだろうか?」といった都市特
有の大気現象の理解を深めることだったからです。

最近は, 気候変動への関心が高いことから，「都市の気 候は将来どうなるのだろうか?」という視点で都市スケ 一ルの気候の研究が活発になされています。気候変動の 研究が取り扱う内容は，温熱環境や降水はもちろんのこ と, 人間の健康やエネルギ一需要への影響まで拡大して おり, 都市気候学と他分野の垣根はますますなくなりつ つあります。将来予測の研究分野では, IPCC の次期報告 書（第 6 次評価報告書, AR6) への貢献が期待されてい ます。これについては, 第3 節で詳しく紹介します。

\section{2. 気象学分野における都市の気温とは?}

第 1 節で述べたように, 気象学・気候学の分野では, 伝統的に，ヒートアイランド現象をメソスケールの大気 現象とみなして研究してきました。これが意味するとこ ろは, 気候学・気象学で定義されるヒートアイランド現 象は, 都市（あるいは都市圈）が存在することによって 都市（あるいは都市圈やその風下地域）の気温が全体的 に高くなる現象であるということです。都市内のある場 所の気温だけが局所的に高くなるマイクロスケールの現 象を指してはいません，このため，ヒートアイランドの 強さ（大きさ）を評価する際に用いる都市の気温の定義 は，局所的な影響を受けずに，都市全体の影響だけを受 けている気温ということになります。この場合，都市の 気温は, 都市内のオープンスペースで地表面状態が草地

* 1 筑波大学計算科学研究センター 教授 (kusaka@ccs.tsukuba.ac.jp) Professor, Center for Computational Sciences, University of Tsukuba 
である場所の気温，もしくは，ある地域内の多数の観測 地点の気温の平均值として定義されます。気象庁のアメ ダス気温は前者, 気象モデル・気候モデルで計算される 気温は後者を意味します。

\section{3. 都市気象モデル, 都市気候モデル}

風工学分野にとって，CFD モデルを用いた数值シミュ レーションが非常に重要な研究手段であるのと同じく, 気象学・気候学分野でも, 気象モデル・気候モデルを用 いた数值シミュレーションは非常に重要な研究手段とな っています。天気予報, 気候変動予測などは, 全て, 数 值シミュレーションモデル (以下, 数值モデル) なくし て成り立ちません。都市気象学・都市気候学分野も例外 ではありません。

気象学・気候学分野で利用される数值モデルは，再現 したい現象のスケールによって大きく 3 種類に分けられ ます。一つ目は, 地球規模の気象・気候をシミュレート するモデルで, 大気大循環モデルや全球気候モデルなど が代表的です。大気大循環モデルの英語名は, General Circulation Model, 全球気候モデルは Global Climate Model で，どちらも GCM と呼ばれています。大気大循環モデ ルは日々の天気予報などに使われることを目的に開発さ れ，全球気候モデルは，気候変動予測などを目的に開発 されました。GCM の水平分解能は, 従来, $100 \mathrm{~km}$ 程度で あったため, 都市はまったく表現されていませんでした。 しかしながら, 水平分解能が向上し, さらには, 都市の 熱収支をシンプルに表現できる都市キャノピーモデル

(Urban Canopy Model, UCM ; 第 4 節で紹介します) が 2000 年代の初頭に開発されるようになると, GCM にも UCM を搭載し, 都市の気温をより精度良く計算しようと いう試みがなされるようになりました ${ }^{1)}$ 。そして, UCM を搭載した GCM を用いて地球温暖化とヒートアイラン ドの両方を考慮した気候変動研究や，ヒートアイランド 対策効果の評価などが行われるようになりました ${ }^{2)}$ 。

二つ目の数值モデルは, 領域気象モデル・領域気候モ デルです。昔は,メソスケールモデルと呼ばれていまし たが, 現在では, 計算対象がメソスケールの現象に限ら ないことから，その名前で呼ばれることは少なくなりま した。領域気象モデルが対象とする典型的な範囲は, 都 市スケールから大陸スケールくらいで, 水平分解能は数 $100 \mathrm{~m}$ 数 $10 \mathrm{~km}$ 程度です。領域気象モデルは, 早くから 都市気象の研究に使われていました。1970 年代〜1990 年 代までは，都市を粗度が大きく，アルベドが小さく，熱 容量が大きく, 乾いている土壌と見なして熱収支式を解
くことで，メソスケールモデルの中で都市を表現してい ました ${ }^{3)}$ 。1990 年代から, 汎用モデルに位置づけられる MM5（The fifth-generation Mesoscale Model, ペンシルベニ ア州立大学とアメリカ国立大気研究センターで共同開発 された領域気象モデル) やRAMS (Regional Atmospheric Modeling System, コロラド州立大学で開発された領域気 象モデル）が世界中で使われるようになり，2000 年代に なるとヒートアイランドのシミュレーション研究が増え ていきました ${ }^{4)}$ 。2005 年に当時の最新鋭モデルであった WRF (Advanced Research - Weather Research and Forecasting Model, アメリカ国立大気研究センターで開発された領 域気象モデル) に UCM が導入され，そのバージョンが リリースされると，世界中でWRF を用いた都市気象シミ ユレーション研究が行われるようになりました5

2010 年代になると, WRF に代表される領域気象モデル は，都市の将来気候予測実験にも使われるようになって いきました ${ }^{67,8)}$ 。そして, 積分期間が長くなるにつれ, 領 域気象モデルは領域気候モデル (Regional Climate Model, RCM) と呼ばれるようになりました。また, GCM を境界 值として地域の気候を計算する手法は, 力学的ダウンス ケール実験（もしくは，力学的ダウンスケーリング）と 呼ばれるようになりました。力学的ダウンスケーリング 関係の研究成果については, 第 5 節でもう少し詳しく紹 介します。

三つ目のモデルは，都市街区内の現象を対象にしたマ イクロスケールの数值モデルです。このモデルは, 風工 学分野における CFD モデルとよく似ています。ただし, モデルの予報変数として気温ではなく温位を用いるなど, 異なる点もあります。また, 基礎方程式系には, 水蒸気, 雲水, 雨水などの保存式を持ち, そのため, 予報変数と して, 水蒸気, 雲水, 雨水などの混合比を持つ点も異な ります。さらには，太陽放射モデル・大気放射モデル・ 地表面モデル・雲物理モデルといった大気の物理モデル （サブモデル）を含んでいる点，現象の時間変化，特に 日変化を重視する点も異なります。都市気象学・都市気 候学のためのマイクロスケールの数值モデルには，一般 的な気象学の数值モデルとは異なり, 建物や街路樹の効 果, 人工排熱の効果などが考慮されています 9,10)。そして, これらについては, 建築工学分野の知見を大きく取り入 れています。

4. 都市キャノピーモデルについて

ここでは，世界で最も広く使われている領域気象モデ ルWRF を例にとり, WRF に搭載されている 3 つの UCM 
を紹介します5) (図 1)。WRF ユーザの 93\%がオプション 1 を選んでいるという調査結果を考慮して ${ }^{11)}$ ，はじめに, 単層キャノピーモデルについて紹介します。WRFに搭載 されているUCM のオプション 1 は，著者らによって開 発された単層キャノピーモデル（Single-Layer Urban Canopy Model, SLUCM）で, 都市表面と大気の間の熱, 水, 運動量の輸送量の計算を目的に開発されたものです。 これらの值は, 屋根面・壁面・道路面で計算されるフラ ックスの面積加重平均值として計算されます。キャノピ 一層内の気温は診断的に計算され, 風速は解析的に計算 されます。熱収支やフラックスで見た場合の単層キャノ ピーモデルのパフォーマンスは，多層キャノピーモデル に近いことが確認されています ${ }^{12)}$ 。また，気候計算でも 高精度な結果が得られることも確認されています。)

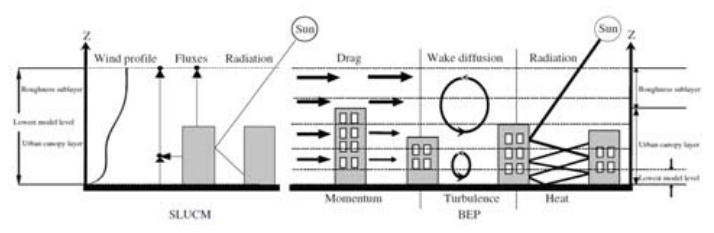

図 1 WRF に導入されている UCM の概念図

左側は SLUCM 内での風速・フラックス・日射の概念 で, 右側はBEP 内でのそれらの概念 5)

オプション 2 は, 多層キャノピーモデル(Building Effect Parameterization, BEP)です。キャノピー層内の風と温度の 鉛直分布を予測計算することができます ${ }^{13)}$ 。オプション 3 は，多層キャノピーモデルにビルエネルギーモデル (Building Energy Model, BEM)を結合したものです ${ }^{14)}$ 。一般 的な UCM での人工排熱の取り扱いと異なり，BEM では 外気温や建物内の気温・設備・人間活動に合わせて人工 排熱が計算されます。なお，WRF の開発機関である NCAR は, GCM も開発しており, そこでもWRF の UCM と類似の UCM が搭載されています。

5. 領域気候モデルを用いた都市スケールの温熱環境研究 都市スケールの温熱環境のシミュレーション研究は, 主として，領域気候モデルを用いて行われます。1990 年 代〜2000 年代は, ある典型的なヒートアイランド出現日 を対象に数日程度のシミュレーションが行われていまし たが，2010 年代以降, 地球温暖化研究の活発化に伴い, 数ケ月〜数年の都市気候シミュレーションも活発に行わ れています。
短い時間スケールの現象を対象とした最近の研究とし て, 極端高温現象の研究があげられます。極端高温現象 は，都市に限らず発生しますが，人々の多くは都市に住 んでいるため, 都市の極端高温現象が注目されています。 日本の場合, 極端高温は, フェーン現象によって出現す るため, フェーンを対象とした日本最高気温記録の要因 解明などが行われています ${ }^{15,16}$ 。また，極端高温現象に 及ぼすフェーンとヒートアイランドの比較評価なども行 われています ${ }^{17) 。 N i s h i ~ ら に よ る W R F ~ に よ る シ ミ ュ レ ー ~}$ ション結果は, 新潟の夜間の極端高温現象（深夜でも $\left.30^{\circ} \mathrm{C}\right)$ に対して, フェーンとヒートアイランドが同程度, 昇温に寄与していたことを示しており，これはヒートア イランドが極端高温の出現に無視できない貢献をしてい ることを意味しています。

海外では, 都市の極端高温を熱波 (heat wave) の視点 で研究することが多いように感じます。熱波というと偏 西風の蛇行が生み出すブロッキング現象によるものが有 名ですが，一般的には，広い範囲で数日間以上の連続し た極端高温であり，原因は含まれてはいません。過去の 有名な熱波事例には, 2003 年, 2019 年の欧州の熱波と 2006 年のアメリカの熱波があります。2003 年の熱波によ って欧州で 7 万人以上の熱中症死亡者が出て以来，熱波 は広く関心が持たれるようになりました。都市の温熱環 境との関係としては,「熱波時の都市の温熱環境の実態調 査」や「熱波とヒートアイランドの相乗効果」,「将来の 熱波時のヒートアイランド」に関する研究などがありま す。18,19,20,21,22) 研究の多くは, 熱波時にはヒートアイラン ドは強まり，都市もまた熱波を強めるという結果を得て います。また，欧州の都市は（普段涼しいため）熱波に 脆弱で，対策が必要であるという提言や，緩和策導入効 果の評価もなされています。

時間スケールの長い研究としては, やはり, 気候変動 研究が第一にあげられます。将来の都市の温熱環境を予 測する研究や, 過去から現在, そして将来までの都市の 発展が同地域の気候に及ぼす影響などが, 数值シミュレ ーションによって評価されています。また，複数の将来 都市シナリオを用いた将来都市気候予測の研究も行われ ています $23,24,25,26)$ 。東京やブリュッセルのようにすでに発 達した都市の場合, 今後の気温上昇はヒートアイランド ではなく温暖化によって引き起こされると予測されてい ます 27,28) (図 2)。そのため, コンパクトシティのように 都市構造を変化させたとしても, その効果はかなり小さ いことがシミュレーションによって示唆されています ${ }^{24)}$ (図 3)。一方で，東南アジアの大都市のように，今後も 
発展し続けると予想されている都市の場合，東京とは大 きく異なる結果が得られています。例えば, ベトナム最 大の都市であるホーチミンは, 現在 (2009年) から 2050 年までの都市化による気温上昇量は, 将来も都市が発展 し続けるため (図 4), 今後の温暖化による気温上昇量と 比べて無視できないレベルにあることがシミュレーショ ンによって示唆されています ${ }^{29)}$ (図 5)。私のレビューが 不十分である可能性はありますが，東南アジアの途上国 の都市気候将来予測研究の多くが日本発のようであり, 途上国の都市気候研究に対する日本の研究グループの貢

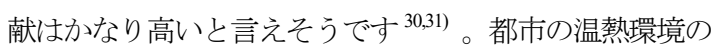
将来予測のなかには, 少数ではありますが, 将来の都市 化と大陸スケールの気候変動の相互作用に着目寸る研究

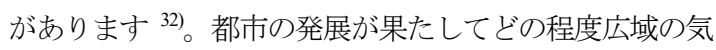
候変動に影響を与えるのか?さらなる研究が望まれます。

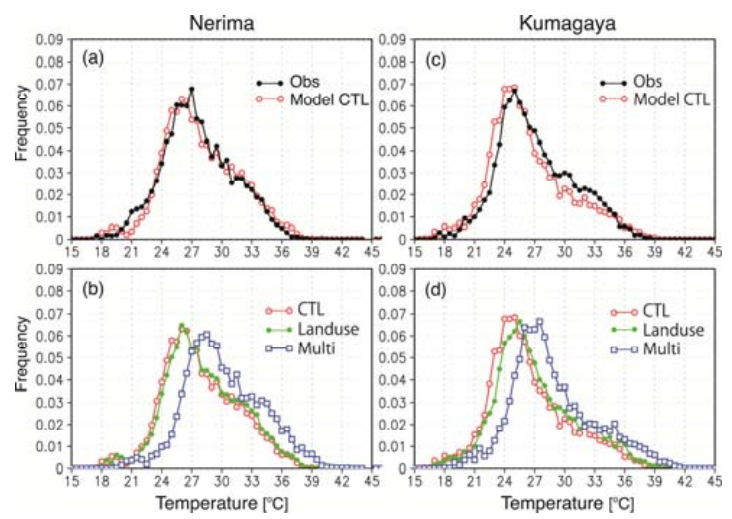

図 2 練馬と熊谷における地上気温の出現頻度 上図は観測值 (黒線) とモデルによる再現実験（赤線） の值, 下図は再現実験の結果 (赤線), 将来の都市化時の 值 (緑線), 将来の温暖化時の值（青線）

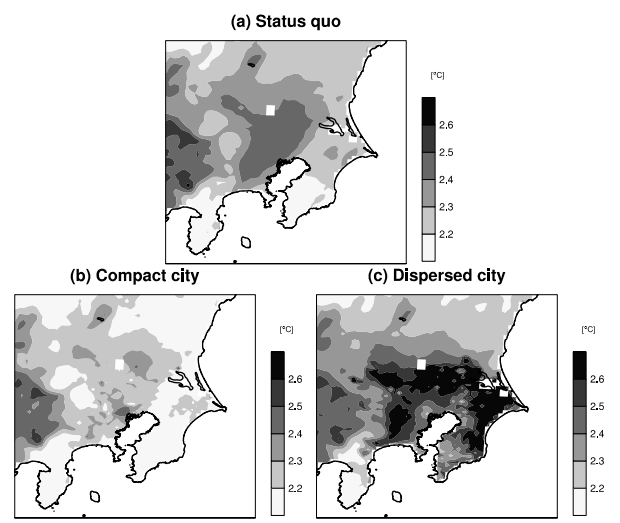

図3 WRFによって計算された 2000 年代から 2050 年 代までの 8 月の地上気温の昇温量 ${ }^{24}$

(a) 将来の都市が現在と同じ場合, (b) コンパクトシテ イになった場合, (c) 分散都市になった場合 $-185(7)-$

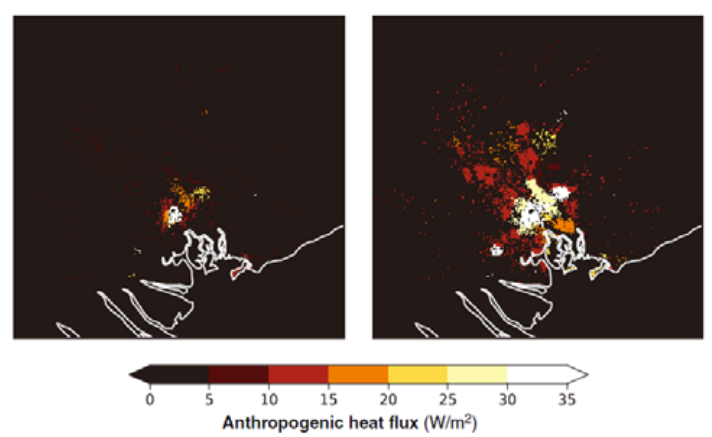

図4 ホーチミン市における日平均人工排熱分布 左困が 2009 年 4 月現在, 右図は 2050 年 4 月の推定值 (Doan and Kusaka 2018 ${ }^{29)}$ の Fig. 3 の一部抜粋)

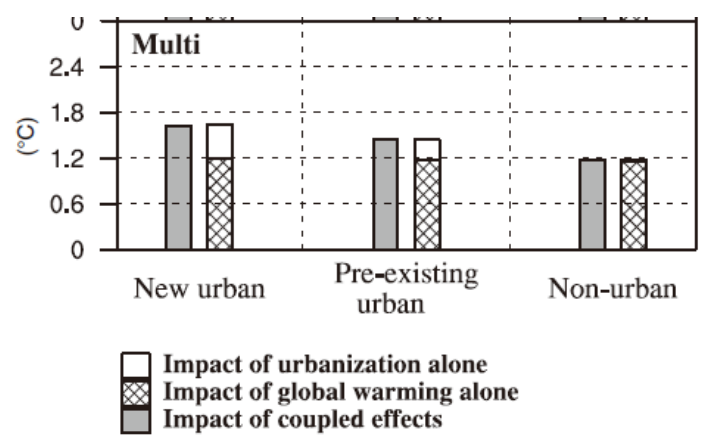

図 5 ホーチミン市におけるRCP4.5 シナリオ下での 2010 年から 2050 年までの気温上昇量

左列，中央，右列の 2 つ棒グラフは，それぞれ，今後 の開発地域, 現在・将来の都心, 現在・将来の郊外にお ける都市化と温暖化の効果

(Doan and Kusaka 2018 $8^{29)}$ の Fig. 17 の一部抜粋)

過去 30 年間が気象モデルのコミュニティーモデル化 （世界共通ツール化）の時代だとすれば，今後は都市デ 一タベースの共有化の時代になると著者は予想していま す。少し前から, 都市気候研究者たちは, 世界各地の都 市のタイプを 17 種類に類型化する取り組みを行っていま す ${ }^{33)}$ 。この類型化は Local Climate Zone (LCZ) と呼ばれて いて, 世界中で研究が盛んに行われています。その後, 世界各都市を対象として, 都市気候モデルなどに必要な 都市表面パラメータやエネルギー消費のデータベースを LCZ 毎に作成する国際プロジェクト WUDAPT が始まり ました ${ }^{34)}$ 。現在では, 様々な研究機関が世界の人工排熱 
マップの作成に取り組んでいます。日本では東京工業大 学の神田学研究室が取り組んでいます。WUAPT をはじ めとするこれらのデータベースは, 都市気候シミュレー ション研究への貢献はもちろんのこと， Global Urban Climatology 研究全体を支える重要な世界共有データにな ると期待されています。

\section{6. 都市の温熱環境が雲, 降水に及ぼす影響}

都市の温熱環境は，風や，雲，雨に影響を与えると考 えられています。「都市はなぜ雲を作り, 雨を降らすのだ ろうか? というのは, 都市気象学・都市気候学分野に おける伝統的かつ重要なテーマの一つです。1970 年代に は，この分野としては大変大きなプロジェクトと言える 「METROMEX」プロジェクトが米国セントルイスで行 われ，当時としては最新技術であった気象レーダーや 3 次元メソスケールモデルなどを用いて, 都市と降水の関 係を調查しました ${ }^{35)}$ 。現在でも，米国や中国を中心にレ ーダーや数值モデルを用いた事例研究が精力的に続けら れています。 ${ }^{36,37,38,39)}$ 東京に関しては, 暖候期に降水量が 増加傾向にあることを観測事実から統計的に示寸研究や 40), 事例研究の不確実性を軽減するために, 多数の数值 実験結果を用いて都市が降水に与える影響を統計的に検 定するという研究がなされています ${ }^{41,42)}$ 。図 6 は, 都市 化によって都市域とその風下では短時間強雨が統計的に 有意に増加したことを示した 243 アンサンブル実験の結 果です ${ }^{42)}$ 。都市の発展は, 都市域およびその風下の対流 性降水を増加させ, さらに内陸の降水量を減少させるこ とが，統計的に示されています。この原因は，ヒートア イランドによる都市域での地上気圧の低下と，それによ る海風・海風前線の強化と水蒸気輸送量の増大であるこ とが分かりました。これらを含む多くの研究により、最 近では東京が降水を増加させることに対してコンセンサ スが得られてきたように感じます。現在の関心はエアロ ゾルの影響や極端降水に移りつつあり, それらの研究も 精力的に行われています。ただ, 本稿のテーマは温熱環 境なので, 都市降水の話はこれくらいにして, 本稿を終 わりにします。

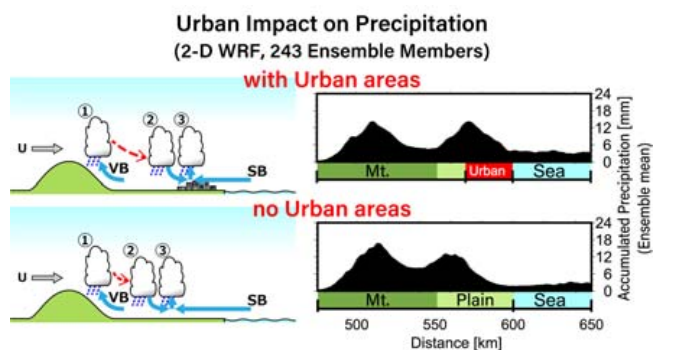

図 6 沿岸の大都市が夏季の短時間強雨に及ぼす影響 左図は海風と対流雲の概念図, 右図は降水分布。右上 図は都市あり実験での降水量分布，右下図は都市なし実 験での降水量分布図。(Kusaka et al. 2019 $9^{42}$ の Graphical Abstractより)

\section{謝辞}

本研究の一部は, (独) 環境再生保全機構の環境研究総 合推進費（2-1905）により実施された。

\section{参考文献}

1) Oleson, K. W., Bona, G. B., Feddema, J., and Jackson, T. "An examination of urban heat island characteristics in a global climate model", International Journal of Climatology, Vol. 31, pp. 1848-1865, (2011).

2) McCarthy, M. P., Best, M. J. and Betts, R. A., "Climate change in cities due to global warming and urban effects", Geophysical Research Letters, Vol. 37, L09705, (2010)

3) Kimura, F. and Takahashi, S., "The effects of land-use and anthropogenic heating on the surface temperature in the Tokyo metropolitan area: a numerical experiment", Atmospheric Environment, Vol. 25B, pp. 155-164, (1991)

4) Kanda, M., Inoue, Y., Uno, I., "Numerical study on cloud lines over an urban street in Tokyo", Boundary-Layer Meteorology, Vol. 98, pp. 251-273, (2001)

5) Chen, F., Kusaka, H., Bornstein, R., Ching, J. and co-authors, "The integrated WRF/urban modeling system: development, evaluation, and applications to urban environmental problems", International Journal of Climatology, Vol. 31, pp. 273-288, (2011).

6) Kusaka, H., Hara, M., and Takane, Y., "Urban Climate Projection by the WRF Model at 3-km Horizontal Grid Increment: Dynamical Downscaling and Predicting Heat Stress in the 2070's August for Tokyo, Osaka, and Nagoya Metropolises", Journal of the Meteorological Society of Japan, Vol. 90B, pp. 47-63, (2012) 
7) Georgescu, M., Moustaoui, M., Mahalov, A., and Dudhia, J.,"Summer-time climate impacts of projected megapolitan expansion in Arizona", NATURE CLIMATE CHANG, Vol. 3, pp. 37-41, (2013)

8) Georgescu, M., "Challenges Associated with Adaptation to Future Urban Expansion” JOURNAL OF CLIMAT, Vol. 28, pp. 2544-2563, (2015)

9）池田亮作・日下博幸「都市街区気象モデル City-LES の概要」, 本ヒートアイランド学会誌, Vol. 12, pp. 19-22 (2017)

10) Onihsi, R., Sugiyama, D., Matsuda, K., "Super-Resolution Simulation for Real-Time Prediction of Urban Micrometeorology”, SOLA, Vol. 15, pp. 178-182, (2019)

11) NCAR, "WRF physics use survey - August 2015", https://www2.mmm.ucar.edu/wrf/users/wrf physics_surve y.pdf. (2015)

12) Kusaka, H., H. Kondo, Y. Kikegawa, and F. Kimura A., "Simple Single-Layer Urban Canopy Model For Atmospheric Models: Comparison With Multi-Layer And Slab Models", Bound. Layer Meteor., Vol. 101, pp. 329-358, (2001)

13) Martilli, A., Clappier, A., and Rotach, M. W., "An urban surface exchange parameterisation for mesoscale models" Boundary-Layer Meteorology, Vol. 104, pp. 261-304, (2002)

14) Salamanca, F., Krpo, A., Martilli, A., "A new building energy model coupled with an urban canopy parameterization for urban climate simulations - Part I. Formulation, verification, and sensitivity analysis", Theoretical and Applied Climatology, Vol. 99, pp. 331-344. (2010)

15) Takane, Y. and Kusaka, H., "Formation Mechanisms of the Extreme High Surface Air Temperature of 40.98C Observed in the Tokyo Metropolitan Area: Considerations of Dynamic Foehn and Foehnlike Wind", American Meteorological Society, Vol. 50, pp. 1827-1841, (2011)

16) Nishi, A. and Kusaka, H., "Effect of Foehn Wind on Record-Breaking High Temperature Event $\left(41.1^{\circ} \mathrm{C}\right)$ at Kumagaya on 23 July 2018”, SOLA, Vol. 15, pp. 17-21, (2019)

17) Nishi, A., Kusaka, H., Vitanova, L.L., and Imai, Y., "Contributions of Foehn and Urban Heat Island to the Extreme High-Temperature Event in Niigata City during the Night of 23-24 August 2018”, SOLA, Vol. 15, pp.
132-136, (2019)

18) Tan, J., Zheng, Y., Tang, X., Guo, C., Li, L Song, G. Zhen, X Yuan, D., Kalkstein, A, J., Li, F. and Chen, H., "The urban heat island and its impact on heat waves and human health in Shanghai”, Int J Biometeorol, Vol. 54, pp. 75-84, (2010)

19) Zhou, Y. and Shepherd, J. M., “Atlanta's urban heat island under extreme heat conditions and potential mitigation strategies", Nat Hazards, Vol. 52, pp. 639-668, (2010)

20) Li, D and Bou-Zeid, E., "Synergistic Interactions between Urban Heat Islands and Heat Waves: The Impact in Cities Is Larger than the Sum of Its Parts", American Meteorological Society, Vol. 52, pp. 2051-2064, (2013)

21) Ward, K., Lauf, S., Kleinshmit, B., Endlicher, W., "Heat waves and urban islands in Europe: A review of relevant drivers", Science of the Total Environment, Vol. 569-570, pp. 527-539, (2016)

22) Tewari, M., Salamanca, F., Martilli, A., Treinish, L. and Mahalov, A., "Impacts of projected urban expansion and global warming on cooling energy demand over a semiarid region", Atmospheric Science Letters, Vol. 18, pp. 419-426, (2017)

23) Lemonsu, A., Viiguie, V., Daniel, M. and Masson, V., "Vulnerability to heat wave: Impact of urban expansion scenarios on urban heat island and heat stress in Paris(France)", Urban Climate, Vol. 14, pp. 586-605, (2015)

24) Kusaka, H., Suzuki-Parker, A., Aoyagi, T., Adachi, S.A. and Yamagata, Y., "Assessment of RCM and urban scenarios uncertainties in the climate projections for August in the 2050s in Tokyo", Climatic Change, Vol. 137, pp. 427-438, (2016)

25) Yang, L., Niyogi, D., Tewari, M., Aliaga, D., Chen, F., Tian, F., and Ni, G., "Contrasting impacts of urban forms on the future thermal environment: example of Beijing metropolitan area”, Environmental Research Letters, Vol. 11, 034018, (2016).

26) Iizuka, S., "Future environmental assessment and urban planning by downscaling simulations", Journal of Wind Engineering and Industrial Aerodynamics, Vol. 181, pp. 69-78.

27) Adachi, S. A., Kimura, F., Kusaka, H., Inoue, T. and Ueda, H., "Comparison of the impact of global climate change and urbanization on summertime future climate in the 
Tokyo metropolitan area”, Journal of Applied Meteorology and Climatology, Vol. 51, pp. 1441-1454, (2012)

28) Hamdi, R., Van de Vyver, H., De Troch, R. and Termonia, P., "Assessment of three dynamical urban climate downscaling methods: Brussels's future urban heat island under an A1B emission scenario", International Journal of Climatology, Vol. 34, pp. 978-999, (2014)

29) Doan, V. Q. and Kusaka, H., "Projections of urban climate in the 2050s in a fast-growing city in Southeast Asia: The greater Ho Chi Minh City metropolitan area, Vietnam”, International Journal of Climatology. Vol. 38, pp. 4155-4171, (2018)

30) Lee, H. S., Trihamdani, A.R., Kubota, T., Iizuka, S. and Phuong, T.T.T., "Impacts of land use changes from the Hanoi Master Plan 2030 on urban heat islands: part 2. Influence of global warming, Sustainable Cities and Society, Vol. 31, pp. 95-108, (2017)

31) Darmanto, N. S., Varquez, A. C. G., Kawano, N. and Kanda, M., "Future urban climate projection in a tropical megacity based on global climate change and local urbanization scenarios”, Urban Climate, Vol. 29, 100482, (2019)

32) Krayenhoff, E. S., Moustaoui, M., Broadbent, A.M., Gupta, V. and Georgescu. M., "Diurnal interaction between urban expansion, climate change and adaptation in US cities", Nature Climate Change, Vol. 8, pp. 1097-1103, (2018)

33) Stwart, I. D. and Oke, T. R., "Local climate zones for urban temperatures studies", Bulletin of the American Meteorological Society, 93, 1879-1900, (2012)

34) Ching, J., Mills, G., Bechtel, B., See, L., Feddema, J., Wang, X., Ren, C., and co-authors, "WUDAPT: An urban weather, climate, and environmental modeling infrastructure for the Anthropocene", Bulletin of the American Meteorological Society, 99, 1907-1924, (2018)

35) Changnon, S. A., "METROMEX: A Review and
Summary” Boston, MA, American Meteorological Society, (1981)

36) Shepherd, M., "A review of current investigations of urban-induced rainfall and recommendations for the future", Earth Interactions, Vol. 9, pp. 1-27, (2005)

37) Niyogi, D., Pyle, P., Lei, M., Arya, S., Kishtawal, C., Shepherd, M., Chen, F., and Wolfe, B. "Urban modification of thunderstorms: An observational storm climatology and model case study for the Indianapolis urban region", Journal of Applied Meteorology and Climatology, Vol. 50, pp.1129-1144, (2011)

38) Zhong, S. and Yang, X. Q., "Ensemble simulations of the urban effect on a summer rainfall event in the Great Beijing Metropolitan Area. Atmospheric Research", Vol.153,pp. 318-334, (2015)

39) Argüeso, D., Di Luca, A. and Evans, J. P., "Precipitation over urban areas in the western Maritime Continent using a convection-permitting model", Climate Dynamics, Vol. 47, pp. 1143-1159, (2016)

40) Fujibe, F., Togawa, H. and Sakata, M., "Long-term change and spatial anomaly of warm season afternoon precipitation in Tokyo", SOLA, Vol. 5, pp. 17-20, (2009)

41) Kusaka, H., Nawata, K., Suzuki-Parker, A., Takane, Y. and Furuhashi, N., "Mechanism of precipitation increase with urbanization in Tokyo as revealed by ensemble climate simulations", Journal of Applied Meteorology and Climatology, Vol. 53, pp. 824-839, (2014)

42) Kusaka, H., Nishi, A., Mizunari, M., Yokoyama, H., "Urban impacts on the spatiotemporal pattern of short-duration convective precipitation in a coastal city adjacent to a mountain range, Vol. 145, 2237-2254, (2019) 